\title{
A RECORDING SNOW LYSIMETER
}

\author{
By A. HerrmanN \\ (Institut für Geographie der Universität München, 8 München 2, Luisenstrasse 37, Germany)
}

\begin{abstract}
An instrument which continuously records the run-off from a small, well-defined snow cover is described. The lysimeter is reasonably priced and effective, requiring only modest service attention; details of the records which it takes are given also. The relevance of the instrument to snow hydrology and to the energetics of a snow-cover is discussed.

RÉsumé. Un lysimètre à neige enregistreur. On décrit un appareillage pour l'enregistrement continu des écoulements provenant de petites couches de neige bien individualisées. On donne une description d'un mécanisme efficace et de prix raisonnable pour un lysimètre à neige ne demandant qu'un entretien modeste, ainsi qu'un exemple des enregistrements obtenus. On discute ses possibilités d'emploi pour des études d'hydrologie nivale et spécialement du bilan énergétique du manteau neigeux.

Zusammenfassung. Ein registrierendes Schneelysimeter. Es wird eine Messanlage zur kontinuierlichen Aufzeichnung der Abflüsse aus kleinen, festumrissenen Schneedecken vorgestellt. Der Mechanismus eines kostensparenden, aber wirkungsvollen und zudem wartungsarmen Schneelysimeters wird beschrieben, seine Einsatztüchtigkeit durch ein Registricrbeispiel belegt. Ferner wird sein praktischer Nutzen bei schneehydrologischen und speziell schneedeckenenergetischen Fragestellungen diskutiert.
\end{abstract}

\section{INTRODUGTYON}

Recent mass and energy balance studies of glaciers and snow fields of large area have revealed a need for basic investigations into the ablation mechanisms relating to ice and snow (Föhn, 1973; Wendler and Ishikawa, 1973; Ambach, 1976). A study into the development of temperate winter snow covers has been carried out by the Institut für Geographie der Universität München since 1971 ; this research is part of a long-term hydrological research programme (Herrmann and others, 1973). The present study investigates snow-cover development in a catchment region, of area $18.7 \mathrm{~km}^{2}$, situated at the northern edge of the Bavarian Alps (670-I 801 m a.s.1.).

The lysimeter described here was developed in order to obtain detailed information about the run-off from alpine snow covers at low or medium altitudes. Such run-off is initiated by both melting and frequent winter rainfalls. Preliminary results from the study have already been published (Herrmann, 1974) and include estimates of ablation from the snow cover calculated from energy-balance data and from lysimeter records.

A simple water-sampling mechanism, involving only a few instrumental modifications, was added to the lysimeter in 1975 to permit the estimation of the isotopic content of the run-off.

\section{INSTRUMENTATION SYSTEM}

The lysimeter (Fig. I) consists of two parts: a snow-collection area, and a recording unit, connected by a plastic tube.

The snow-collection area is square and $25 \mathrm{~m}^{2}$ in area. This is probably the smallest size which can be used with any confidence that its results can be applied to larger snow covers. Larger catchment areas pose many research difficulties, in particular the problem of collecting and recording large quantities of water.

The snow catchment area is bordered by planks $0.1 \mathrm{~m}$ high. The ground within this border is covered with polyethylene sheet, $0.2 \mathrm{~mm}$ thick; this material is preferred to polyvinyl chloride as its thermal conductivity and radiative properties are more suitable. The ground of the catchment area slopes to a central outlet located in the middle of a border plank. We assume that the liquid which runs into the area from outside, at the upper edge of the area, is balanced by liquid which runs out at the lower border without being recorded. Funnelshaped catchments ought not to be used, incidentally, as inflow which is not compensated by 
outflow can occur, with a circular design, and this leads to a systematic error. However, with a square area, liquid travel times must be taken into account in the calculations; water from different parts of the area will take different times to arrive at the outlet.

The water-collection system consists of a floatation chamber in the form of a plastic barrel (Fig. 2) installed in a pit. The barrel outlet, diameter 1.5 in $(3.75 \mathrm{~cm})$, is some distance above

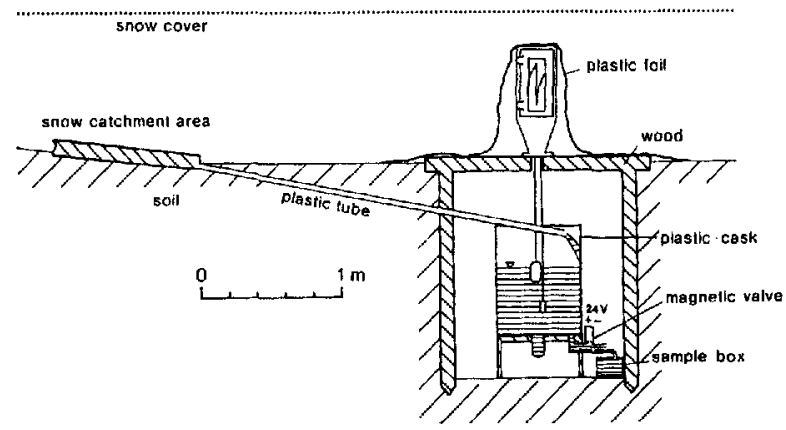

Fig. . The recording snow lysimeter.

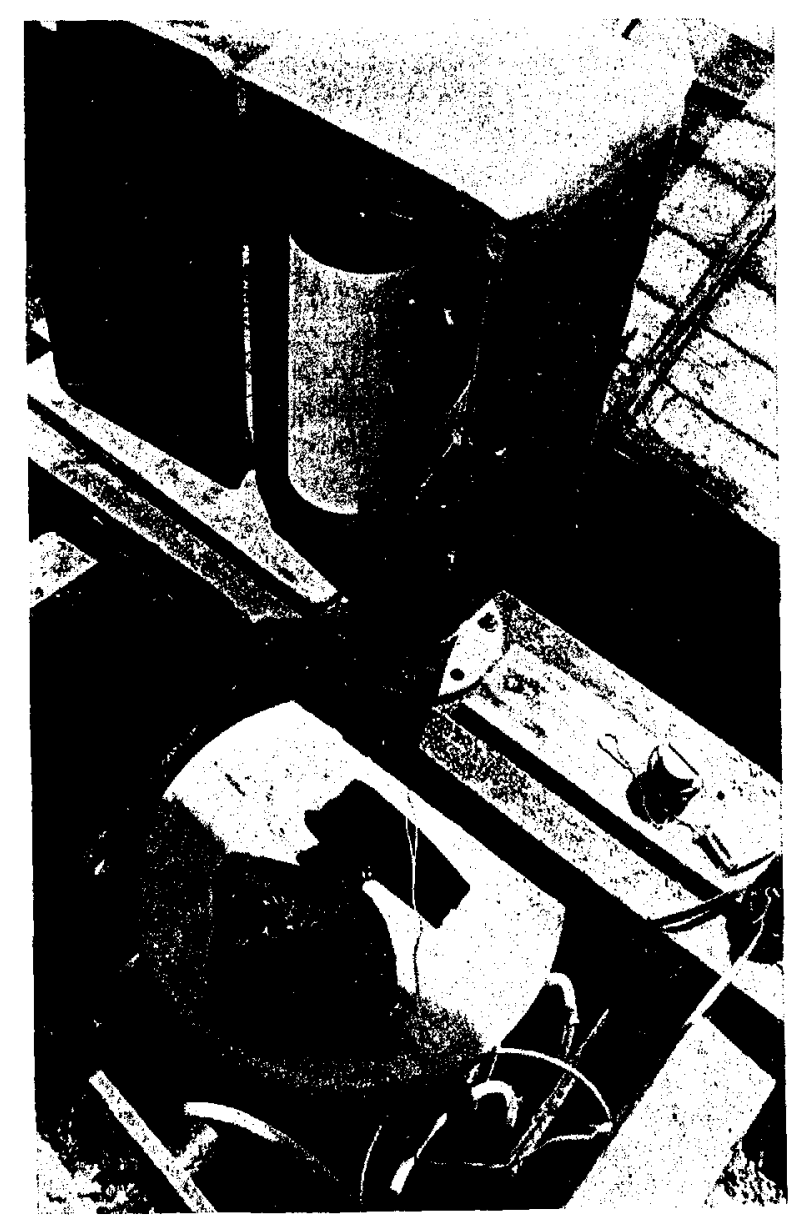

Fig. 2. A photograph of the water-collection barrel and, above it, the water-level recorder. 
the level of the pit base and is controlled by a $24 \mathrm{~V}$ d.c. magnetic valve. This allows the lysimeter to be controlled in remote areas where no mains electricity is available. Two standard accumulators ( $84 \mathrm{~A} \mathrm{~h}$ ) are sufficient to supply the low current requirements of the valve for a whole winter.

The magnetic valve is controlled by two microswitches mounted in the recording unit of the lysimeter, which is an Ott vertical-drum water-level recorder with a variable recording scale (Fig. 2). These switches operate in the following way: When the water level reaches its maximum height of $0.25 \mathrm{~m}$, the recorder pen closes the first microswitch. This allows current to flow to the valve, which opens, and allows water to run out of the barrel. As the water level drops, the recorder pen moves towards the minimum end of its scale eventually closing the second microswitch which shuts down the current and closes the valve again.

The recording drum of the water-level recorder is driven by a robust clockwork mechanism. The drum rotates once in $8 \mathrm{~d}$ producing a linear chart speed of $2 \mathrm{~mm} / \mathrm{h}$. Other speeds are possible as the transmission gears can be changed, but the speed quoted here was found to be the most suitable for establishing the relationships between the volume of water arriving from the catchment area and such quantities as cask dimensions and decay of the recording curves with time.

The pit which contains the recording and collecting units is covered by planks and snow. This maintains the pit at temperatures considerably above freezing point. However, additional protection is recommended for the recording unit which is made largely of metal. The formation of ice on the pulleys and belts of the transmission system can be minimized by isolating the recorder housing with "Styropor" plates. In an emergency, defrosting liquids can be sprayed into the unit to keep the recorder at work. A pit area of $\mathrm{I} \mathrm{m}^{2}$ is sufficient for the water from a previous emptying operation to have soaked into the ground before the next emptying, even with a pit bed of argillaceous morainic deposits.

The readings obtained using this system represent the mean water run-offs during the periods between emptying. If slight modifications of the basic unit are made (Fig. 3) then the water samples can be collected and retained instead of being lost to the ground. Such retention allows analysis of the snow-cover run-off, e.g. for its isotopic composition. The modification consists of the introduction of a central cavity into the bottom of the barrel in which the float is held, with the position of the barrel outlet below the level at which the second microswitch closes the outlet valve. Thus, nearly all the collected water leaves the barrel during the emptying operation. A certain proportion of this outflow can be lead to a $5 \mathrm{dm}^{3}$ sample box
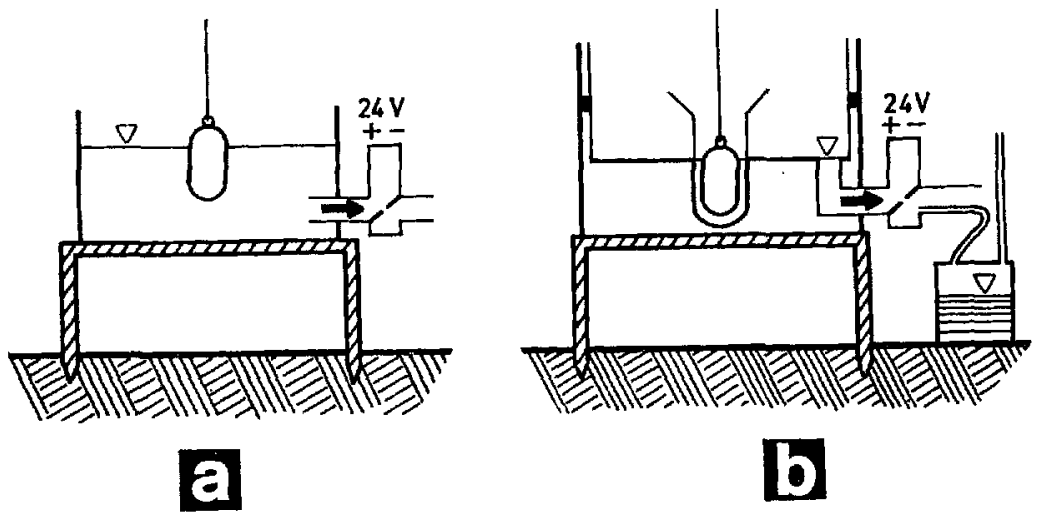

Fig. 3. Tivo alternative configurations for the lysimeter:

a. For the recording of run-off only.

$b$. For the recording and proportional retention of run-off. 
through a $\frac{1}{4}$ in $(0.65 \mathrm{~cm})$ diameter plastic tube inserted in the bottom of the magnetic-valve outlet. The proportion of liquid sampled is controlled using a clip on the tube. Thus, the isotopic proportions in a run-off system can be assessed by analysis of the sample collected.

\section{RESULTS}

Figure 4 shows a recording produced by the snow lysimeter during a period of severe spring ablation. The chart speed was $2 \mathrm{~mm} / \mathrm{h}$ and the recording scale $\mathrm{I}: \mathrm{I}$.

The recording system described here draws curved plots while the floatation chamber is filling, and straight vertical lines while the chamber empties, a procedure which takes about I min. There is, at this chart speed, an upper limit for the accurate assessment of run-off. This upper limit corresponds to the frequent melting during day-time in the catchment area of 25-30 $\mathrm{mm}$ (water column) of the snow cover. For higher run-off rates the recording scale must be changed to $I: 2$.

An interruption of run-off is represented on the recording by a straight horizontal line. When this occurs at the top or bottom of the chart, it may also represent a valve switching failure.

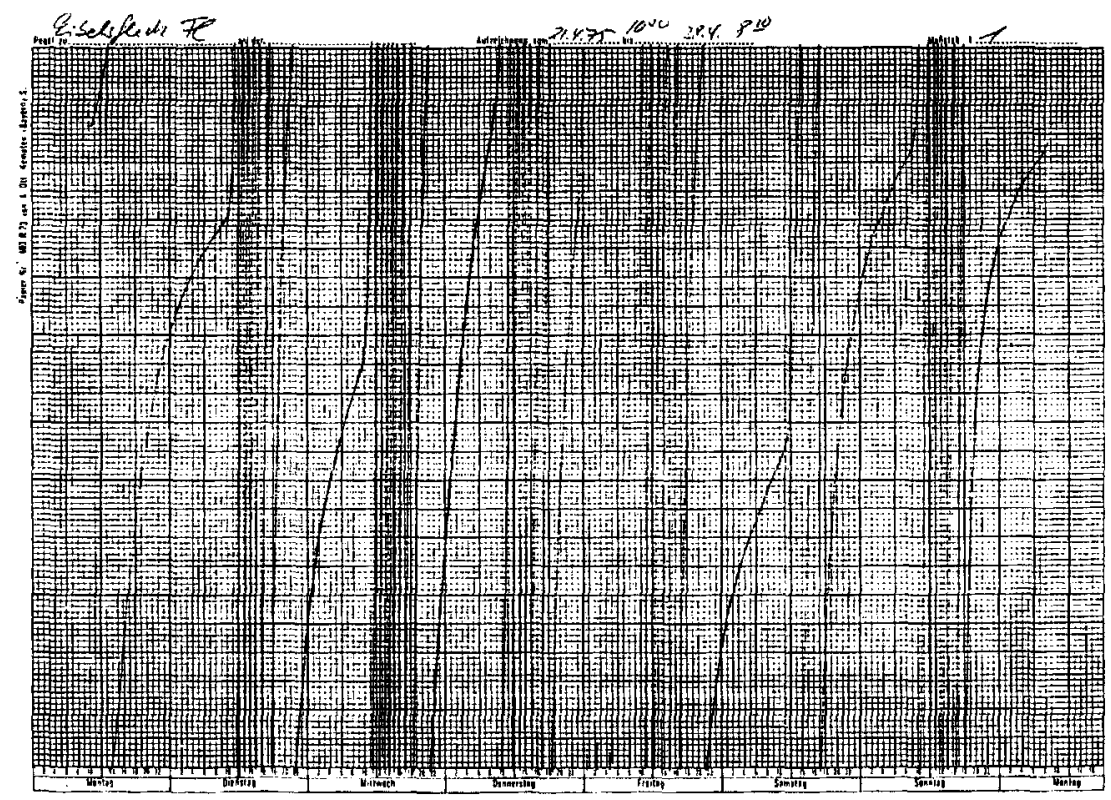

Fig. 4. A recording made by the lysimeter of the run-off from $25 \mathrm{~m}^{2}$ of snow cover at $\mathrm{r}$ 030 $\mathrm{m}$ a.s.l. in the Bavarian Alps, April 1975 (spring ablation). The $25 \mathrm{~cm}$ recording height corresponds to a collection of $75 \mathrm{l}$ of liquid (c. $3 \mathrm{~mm}$ water column) when using a chart speed of $2 \mathrm{~mm} / \mathrm{h}$. (The recording which appears here has been photographically reduced.)

\section{Discussion}

Two recording lysimeters of the type reported here are operating successfully in the research area in the Bavarian Alps, one in an open area and the other in a forest. The energy budgets of the snow catchment areas are estimated simultancously from continuous readings of air temperature, snow temperature, humidity, wind speed, and radiation balance. An instrumental system which is sufficiently comprehensive can enable even very short-term studies to be made into such topics as the mass of local snow cover and variations in the energy balance (Herrmann, 1974). 
Research of this kind yields data which may be used to formulate optimum models of the snow melt and simulations of run-off processes (involving both melting and rain) within a given catchment area (Herrmann, I975). These simulations can be influenced to a considerable extent by the natural transmission and transformation properties of the areas studied, and these properties can be isolated and measured effectively by analysis of synoptic data from lysimeters and hydrographs. Furthermore, the encouraging preliminary experiments of Herrmann and Stichler (1976) into the isotopic content of snow have shown that the interpretation of reliable isotope data obtained with a lysimeter together with run-off data appears to allow some further quantitative insight into the relationships between the direct and delayed run-off of snow melt. Assessments of the contributions made by surface flow, interflow, and ground-water flow to total run-off during snow-melt periods can also be made.

\section{Acknowledgements}

I would like to extend especial thanks to Professor F. Wilhelm and Dr K. Priesmeier, both of the Institut für Geographie der Universität München for their co-operation during the planning and installation of the instrument described here. My thanks are also due to the Flussmeisterstelle Benediktbeuern/Oberbayern for carrying out the excavation work and to the Institut für Radiohydrometrie der Gesellschaft für Strahlen- und Umweltforschung $\mathrm{mbH}$, München, who carried out the construction of the modified water-collection units for the snow lysimeters.

MS. received ${ }_{15}$ March 1977 and in revised form 24 May 1977

\section{REFERENGES}

Ambach, W. 1976. Zum Wärmehaushalt im Akkumulationsgebiet des grönländischen Inlandeises: Interpretation der thermischen Stabilität von kalten Schneeschichten. Polarforschung, Jahrg. 46, Nr. I, p. 46-59.

Föhn, P. M. B. 1973. Short-term snow melt and ablation derived from heat- and mass-balance measurements. Journal of Glaciology, Vol. 12, No. 65, p. 275-89.

Herrmann, A. 1974. Ablation einer temperierten alpinen Schneedecke unter besonderer Berücksichtigung des Schmelzwasserabflusses. I. Schneedecke einer kleinen Freilandtestfläche. Deutsche Gewässerkundliche Mitteilungen, 18. Jahrg., Ht. 6, p. 146-55.

Herrmann, A. 1975. Ablation einer temperierten alpinen Schneedecke unter besonderer Berücksichtigung des Schmelzwasserabflusses. II. Schneedecke eines randalpinen Niederschlagsgebiets. Deutsche Gewässerkundliche Mitteilungen, 19. Jahrg., Ht. 6, p. 158-67. $^{8}$

Herrmann, A., and Stichler, W. I977. Stabile Isotope in einer randalpinen Schneedecke. Sonderforschungsbereich (München) 81, p. 43-65.

Herrmann, A., and others. 1973. Wasserhaushaltsuntersuchungen im Niederschlagsgebiet des Lainbaches bei Benediktbeuern/Oberbayern, von A. Herrmann, K. Priesmeier, F. Wilhelm. Deutsche Gewässerkundliche Mitteilungen, 17. Jahrg., Ht. 3, p. 65-73.

Wendler, G., and Ishikawa, N. 1973. Experimental study of the amount of 1ce melt, using three different methods: a contribution to the International Hydrological Decade. Fournal of Glaciology, Vol. 12, No. 66, p. 399-410. 